\title{
COMMENT
}

\section{THE COSTS OF FREELY GRANTING SPECIFIC PERFORMANCE}

\author{
TIMOTHY J. MURIs*
}

Parties external to the contract formulate and enforce contract law; therefore, the law necessarily has an objective cast. To devise workable rules, these external observers must avoid reliance on detailed knowledge of the thoughts and motivations of the contracting parties. Nevertheless, the ultimate subject of contract law is an agreement that, in many important respects, is essentially subjective. Often only the parties can fully appreciate the needs and desires that led to the contract or fully understand the meaning of what transpired in its negotiation. Consequently, tension exists between the subjective nature of the exchange process and the law givers' need to rely on objective criteria to evaluate that process.

Decades ago, contract law cases and commentary provided a forum for the debate between the subjectivist and objectivist schools. ${ }^{1}$ Inspired by Justice Holmes, ${ }^{2}$ the objectivists taught that the subjective intention of the parties is irrelevant to questions of contract formation and interpretation. Neither an objective nor subjective theory, however, totally explaims the case law ${ }^{3}$ concerning these issues. The ten-

- Professor of Law, University of Miami School of Law and Law and Economics Center. The author is currently on leave as Director of the Bureau of Consumer Protection of the Federal Trade Commission. This comment was largely completed before the author joined the FTC and reflects the author's views, not necessarily those of the FTC or of any individual Commissioner. The author would like to thank the Law and Economics Center for financial support and Louis De Alessi, Patrick Gudridge, William MacLeod, Fred McChesney, Judith Miley, Calvin Roush, Alan Schwartz, Bob Staaf, John Weistart, and Stephen Williams for their helpful comments.

1. See 1 A. Corbin, Corbin on Contracts $\$ 106$ (2d ed. 1962). Compare Hotchkiss v. National City Bank, 200 F. 287, 293 (S.D.N.Y. 1911) (objective theory), affd, 201 F. 664 (2d Cir. 1912), affd, 231 U.S. 50 (1913) with Rickets v. Pennsylvania R.R., 153 F.2d 757, 760-67 (2d Cir. 1946) (Frank, J., concurring) (criticisin of objective theory, especially as expounded by Professor Williston).

2. Holmes' most famous defense of objectivisin is The Theory of Legal Interpretation, 12 HaRv. L. Rev. 417 (1899).

3. See supra sources cited in note 1; see also Farnsworth, "Meaning" in the Law of Contracts, 76 Yale L.J. 939 (1967); Whittier, The Restatement of Contracts and Mutual Assent, 17 CAL. L. REV. 441 (1929). Compare RESTATEMENT OF CONTRACTS, § 71, illustration 2 (1932) (objective 
sion between subjectivism and objectivism also appears in determinations of contractual liability and remedy. This tension underlies discussions of whether a "meeting of the minds" is necessary for contractual liability to attach and whether the courts sliould examine the adequacy of consideration. A determmation of whether contractual liability attaches often turns on whether "substantial" performance has a subjective or an objective meaning: objective criteria apparently require only "reasonably complete" performance; subjective criteria demand performance according to the letter of the contract, which presumably embodies the subjective expectations of the parties. In the field of contract remedies, objectivism often appears to dominate. Courts, having access to information about market prices, often value damages by an objective standard.

Nevertheless, nowhere is the conflict between the subjective and objective aspects of contract law more evident than in the area of remedies. The goal of contract remedies is compensation, an attempt to place the nonbreaching party im as good a position as he would be im if the contract had been performed. It appears, at least on first examination, that protection of a party's subjective value, that is, the value that he, not the market, places on performance, is necessary to accomplish the goal of full compensation. ${ }^{4}$ Unlike market-based damages, specific performance clearly protects subjective value, yet courts refuse to grant specific performance automatically at the request of the plaintiff. In liglit of contract law's commitment to compensation, this recalcitrance requires explanation.

Several authors liave analyzed the limited availability of specific performance in terms of economic efficiency. ${ }^{5}$ Initially, Judge Posner presented an economic justification of the courts' reluctance to grant specific performance. ${ }^{6}$ In a recent article, however, Professor Schwartz challenges this position, arguing that greater availability of specific performance would protect subjective value without increasing efficiency costs. $^{7}$ This comment joms the debate over the economics of specific performance and concludes that despite the goal of protecting subjec-

theory) with Restatement (SECOND) of Contracts \$21, illustration 5 (1979) (subjective theory).

4. See infra note 12 and accompanying text, concluding that the damage remedy adequately protects subjective value in a large number of cases.

5. See Kronman, Specific Performance, 45 U. CHI. L. Rev. 351 (1978); Linzer, On the Amorality of Contract Remedies-Efficiency, Equity and the Second Restatement, 81 Colum. L. Rev. 111 (1981); Schwartz, The Case for Specific Performance, 89 Y ALE L.J. 271 (1979).

6. See R. Posner, Economic Analysis of the Law 95-96 (2d ed. 1977).

7. See Schwartz, supra note 5 , at 278-96. 
tive value, the case for freely granting specific performance is an uneasy one.

Two reasons support this conclusion. First, although the use of market-based damages has an objective cast, it protects subjective value in a wide variety of cases. ${ }^{8}$ Second, despite Professor Schwartz's arguments to the contrary, ${ }^{9}$ the specific performance remedy can create higher costs than the simple damage reinedy. Although Professor Schwartz and others have made important contributions to our understanding of specific performance and its ability to protect subjective value, ${ }^{10}$ the case has yet to be made for full-scale deviation from the traditional judicial reluctance to grant specific performance automatically.

\section{Specific Performance, Market Damages, and Protecting Subjective Value}

Calculating the difference between objective and subjective value is the primary obstacle to recognizing subjective value. Because damages need not be calculated, specific performance avoids this obstacle. Moreover, specific performance gives the non-breaching party exactly that for which it contracted, thereby protecting subjective value. Nevertheless, courts regard specific performance as extraordinary; dannages are the usual remedy for a breach. Does this judicial decision underprotect subjective value?

In a great many cases, awarding market dainages does, in fact, protect subjective value. Assume that a buyer is willing to pay $\$ 125$ for a radio, but competition forces the seller to offer it for $\$ 100$. The buyer accepts the offer, but when the inarket price riscs to $\$ 110$, the seller breaches. Although the buyer personally valued the contract at $\$ 25$ above its cost, a court would award the buyer damages of $\$ 10$ (the difference between the market price and the contract price, often called "market damages"), plus any reasonable expenditures necessary to acquire substitute performance. If the buyer can obtain the same radio from another seller at $\$ 110$, the nnarket damages will allow the buyer to buy elsewhere and obtain the same subjcctive satisfaction as if he was unable to purchase the substitute and had received damages of $\$ 25$. In essence, the buyer obtains specific performance of his contract through

8. See infra text accompanying notes $11 \& 12$.

9. See Schwartz, supra note 5, at 278-96.

10. For a more complete discussion of the economic issues relevant to protecting subjective value, see Muris, The Cost of Completion or Diminution in Market Value: The Relevance of Subjective Value, 12 J. LEG. STUD. (1983) (forthcoming). 
the market." Thus, the existence of subjective value in excess of market value is a necessary, but not a sufficient, condition for the market damage formula to fail to compensate the non-breaching party adequately. For the damage reinedy to underprotect subjective value, market damages must be inadequate. ${ }^{12}$

Under present law, the primary consideration in determining whether market damages are inadequate to protect subjective value is whether the good is unique.13 The nonbreaching party's actions at breach illustrate the uniqueness test. Taking the case of a seller's breach, if the buyer finds a perfect substitute for the seller's performance, then damages covering the greater price of the substitute plus the additional transaction costs render the buyer indifferent between breach and performance of the original contract. With soine breaches, however, the proper substitute for a court to use in calculating damages is not obvious. Reliance on the nonbreaching party's assertions about what substitute he considers relevant would encourage exaggerated claims. An objective test, sucli as a reasonable-nian standard, would be of little help when wide disagreenent exists about the values of the substitutes, for example with works of art. Thus uniqueness is anotlier way of stating that the cost of judicially evaluating the proper substitutes is not worth the effort. ${ }^{14}$

11. The situation is different if the buyer, perhaps because the seller makes his own brand of the commodity, values performance from this seller more than from any other seller. Unlike other buyers, that buyer will not consider other brands perfect substitutes, and the market remedy is imadequate.

12. More formal economics can be used to analyze the problem of objective-subjective differences. Under the primciple of diminishing marginal utihty, the buyer will value initial units delivered of a given good higher than subsequent units. See Goetz \& Scott, Liquidated Damages, Penalties and the Just Compensation Principle: Some Notes on an Enforcement Model and a Theory of Efficient Breach, 77 Colum. L. REv. 554, 570-71 (1977). Moreover, when a consumer is the nonbreaching party, the difference between subjective value and market value equals consumer surplus.

13. See 5 A. CoRBIN, supra note 1; Kronman, supra note 5, at 355-58; Schwartz, supra note 5, at 272-74 (1974); Restatement OF CoNTRACTs $§ 361$ (1931); RestatemeNT (SECOND) OF CoNTRACTS $§ 360$ (1979).

14. Sce Kronman, supra note 5, at 358-65; Schwartz, supra note 5, at 275. In the case law, land is presumptively unique. See 5A A. CoRBIN, supra note 1, at § 1143; Kronman, supra note 5, at 355; Schwartz, supra note 5, at 272-73; RESTATEMENT OF CONTRACTS \& 360 (1932); RESTATEMENT (SECOND) OF Contracts § 360, comment e (1979); see also Harris, Ogus \& Phillips, Contract Remedies and the Consumer Surplus, 95 LAw Q. Rev. 581, 587-88 (1979) (English cases). A similar presuniption is applied to family heirlooms and other items of personal property that have a value to the party seeking specific performance and no value, or a much smaller value, to others. See 5A A. Corbin, supra note 1, at \$ 1142; Kronman, supra note 5, at 355-56; RESTATEMENT OF Contracts \$361, comment e, illustration 1 (1932); RestatemENT (SECOND) of CoNTRACTs, comment b, illustrations 1 \& 2 (1979). For a good listing of cases involving chattels in which subjective and objective value probably differred, see $11 \mathrm{~S}$. WILLISTON, A TREATISE ON THE LAW of CoNTRACTs $688 \mathrm{n} .2$ (3d ed. 1968). Of course, land need not necessarily involve subjective 
The importance of subjective value as a factor determining uniqueness varies. In some situations, the proper substitutes can be difficult to determine even by a reasonable-man test, making a calculation of the market damages uncertain and speculative. In these situations, the costs of the damage calculation make the market remedy inadequate whether or not the buyer has a subjective value different froin the market value. ${ }^{15}$ In other situations, the buyer could claim that proper substitutes are easy to identify for other buyers, but not for him, because of some attribute he does not share with other buyers. For example, if one contracts to store his furniture with another who refuses to return it, furniture of the same style, produced at exactly the same time and place, may be available as a base for determining damages. Nev-

value problems. For example, when land is purchased for speculation, damages are adequate. See id. at 588. For a good discussion of the reasons for granting specific performance in a case in which the court appeared to understand the relevance of the difference between objective and subjective value, see Paddock v. Davenport, 107 N.C. 710, 12 S.E. 464 (1890).

Both of the Restatements of Contracts indicate awareness of subjective value as well, at least as to sentimental value. See RESTATEMENT OF CONTRACTS $\$ 361$, comment e, illustration 3 (1932); RESTATEMENT (SECOND) OF CONTRACTS $\$ 60$, comment b, illustration 2 (1979). The illustrations, however, support other strains of analysis. The Restatement illustration reads:

A contracts to sell to B the 21-foot racing sloop "Pollyanna," this sloop being one of a class of substantially identical boats manufactured by a particular boat builder. Although other boats of this class are easily obtainable in the market, A knows that B believes that the "Pollyanna" is a witch in light airs and is, therefore, superior to most of the others. To prove that another of the class is her equal, it would be necessary to try out an indefinite number of such boats in a series of races. A decree compelling $A$ to sell the sloop as agreed may properly be granted.

RESTATEMENT OF CONTRACTS $\$ 361$, comment e, illustration 3 (1932). Although "superior to most of the others" makes the point somewhat ainbiguous, the next to last sentence indicates a desire to ground an award of specific performance on the difficulty in providing dainages, not on B's subjective behief. The Restatement (Second) reads:

A contracts to sell to B the racing sloop "Columbia," this sloop being one of a class of similar boats manufactured by a particular builder. Although other boats of this class are easily obtainable, their racing characteristics differ considerably and B has selected the "Columbia" because she is regarded as a witch in light airs and, therefore, superior to most of the others. A repudiates the coutract and B sues for specific performance. Specific performance may properly be granted.

RESTATEMENT (SECOND) OF CoNTRACTS \$ 360, comment b, illustration 2 (1979).

The damages point is dropped, but a discussion of objective variances between the boats is added. If the objective points are used as evidence from which to infer subjective differences in belief regarding this class of boats, the analysis is consistent with that of this comment.

15. Some consuner purchases are marginal; that is, objective and subjective values are equal. In economic theory, consuiners will purchase a commodity until, for the last unit purchased, subjective and objective values are equal. (An economist would state that such a purchase creates no consumer surplus. See supra note 12.) The concept of marginality does not diminish the importance of subjective value for contract law. When the breach includes purchases other than the marginal unit, subjective value will exist. Moreover, the discrete nature of the commodity nuay prohibit a inarginal purchase. Almost all products are sold in finite units, and an individual's marginal purchase might be at some quantity between the ainounts offered. Both discreteness and breach involving non-marginal units will be common in real-world markets. See generally G. StIGLER, THE TheORY OF PRICE 78-81 (3d ed. 1966) (analytical discussion of consumer surplus). 
ertheless, if the original furniture had been in the owner's family for generations, the other furniture may be a poor substitute to him. ${ }^{16}$ The basis for finding the market remedy inadequate in this case is protection of subjective value.

It inay be that courts are too restrictive in applying this latter use of the uniqueness test. In particular, courts nay not adequately recognize that soine substitutes for even standardized products inay be valued less by soine buyers than by others. ${ }^{17} \mathrm{~A}$ purchaser who has excellent success with one brand of a product, yet not with others, may accordingly value the one brand inore despite the presence of equal cost competitors. Following Professor Schwartz's suggestion and freely granting specific perfornuance would presumably protect subjective value in such cases. ${ }^{18}$

\section{Can Automatically Granting Specific Performance RAISE Costs?}

Because expanding the circumstances under which specific performance is granted would increase protection of subjective value, expansion is undoubtedly beneficial unless specific performance creates costs that outweigh this benefit. So1ne commentators, nost notably Judge Posner, have argued that specific performance is indeed inore costly. ${ }^{19}$ Professors Kronman and Schwartz contend, however, that specific performance need not cost more than awarding damages.

\section{A. Judge Posner's Analysis.}

Suppose a buyer contracts with a seller to have a spare machine part custom-built for delivery in 30 days at a cost of $\$ 10,000$. A second buyer, who has a nore immediate need for the part than the first buyer, then offers the seller $\$ 20,000$. The first buyer could be fully protected by contracting elsewhere at $\$ 12,000 .^{20}$ If specific perfornance is available, the first buyer will threaten to deinand it to force the seller to share soine of its gain from breach. That gain equals the second

16. See Downing v. Williams, 238 Ala. 551, 191 So. 221 (1939).

17. See Schwartz, supra note 5, at 276.

18. Id. Moreover, as Professor Schwartz argues, other reasons exist to expand specific performance, including the frequent under-coinpensation of damage awards. Id.

19. See R. POSNER, supra note 6, at 95-96.

20. An alternative view of the facts would have the first buyer cover at $\$ 10,000$ and the delay in delivery cause $\$ 2,000$ damage. In any such example, its "realisn" will depend on explaining why the second buyer pays the higher price. Schwartz, supra note 4, at 285, uses an example in which dcmand rises and the second buyer agrees to pay a price higher than the eventual new equilibrium price. 
buyer's price less damages to the first buyer. ${ }^{21}$ Thus the first buyer might agree that the seller will pay $\$ 5,000$ for the "right" to breach the origimal contract. Both parties benefit: after paying $\$ 12,000$ to buy elsewhere, the first buyer gains $\$ 3,000$; after paying the first buyer, the seller will receive more from the second buyer $(\$ 15,000)$ than it would have from the first buyer $(\$ 10,000)$.

Contract law does not, however, provide any guide as to what part of the gain the seller should share with the first buyer, and a wide range of amounts-all of those between $\$ 2,000$ and $\$ 8,000$-will benefit both parties. Accordingly, the negotiations between the seller and the first buyer could be extensive. Whatever amount they agree on, these negotiations only redistribute wealth between the parties. In other words, the same total benefit can be obtained through use of a damage remedy that avoids negotiation between the seller and the first buyer over the first buyer's right to specific performance. If the law provides an easily calculable damage standard, the seller would be able simply to send a check for that amount to the first buyer and avoid costly negotiation.

\section{B. The Effect of the Uniqueness Test on the Costs and Benefits of Specific Performance.}

Because specific performance increases costs, it must either produce compensating benefits or avoid other costs to be desirable. Under the uniqueness test, it does both. Regarding benefits, the uniqueness test fulfills the goal of coinpensation when the damage remedy does not. Regarding losses, when damages are difficult to calculate, specific performance need not increase negotiation costs relative to a damage award. Returning to our example, the seller and the first buyer would negotiate over damages. Given uncertainty over the amount of damages that a court would award, the cost of these negotiations could be high. Thus, although the benefits resulting from specific performance of contracts for unique goods need not always outweigh any costs, under the uniqueness test specific performance is available only when it is less likely to raise negotiation costs and when, measured by contract law's compensation goal, specific performance is superior to damages.

\section{Professor Kronman and the Cost-Increase Argument.}

Professor Kronman has recently questioned the soundness of Judge Posner's argunient that_specific performance raises negotiation costs. Professor Kronman agrees that the remedy can increase negotia-

21. This discussion ignores the first buyer's cover cost and the cost of making the contract with the second buyer. Adding their costs would change only the numbers, not the analysis. 
tion costs in a breach that noves resources to higher-valued uses, such as the exainple discussed above. He nevertheless concludes that "it is certainly not obvious" that freely granting specific performance "would increase the total cost of moving resources to their most efficient uses." 22 Kronman's two arguments in support of this conclusion provide scant support, however, for use of specific performance when the uniqueness test is not met.

First, he argues that in soine cases specific performance "may prevent the transfer of a particular resource to a lower-valuing user and thus eliminate the necessity of an additional exchange shifting the resource back to the origmal promisee."23 In terms of our example, if the first buyer was willing to pay more than the second buyer, he would repurchase the part froin the second buyer if the seller breached. For this result to occur, the first buyer's damage remedy would have to reflect his subjective value inadequately; otherwise, the seller could not profitably sell to the second buyer. In such a case, when the second buyer appears willing to pay more than the contract price, but less than the first buyer's subjective value, then the seller, rather than selling to the second buyer, would prefer to renegotiate with the flrst buyer. Even if the first buyer has hidden his true value, the seller would know that he might gain froin attempting to renegotiate: another contract with the first buyer that builds on their past history of negotiation ${ }^{24}$ might be easier to form than a new one. Thus, Kronman is correct; but, because the scenario hinges on the inadequacy of damages, his point merely provides further support for awarding speciflc performance when market damages are inadequate.

Second, Kronman argues that specific performance "might give promisors an increased incentive to carefully identify their various opportunities before committing theinselves contractually-with the result that resources would be inore likely to flow directly to highervalued uses."25 Referring again to our exainple, the seller already has considerable incentive to contract origimally with the second buyer and thus avoid the costs of negotiating two complete contracts and paying

22. See Kronman, supra note 5 , at 353 n.12. Kronman does not deny that specific performance might increase costs in soine cases. $I d$.

23. $I d$.

24. As long as the seller inust pay the first buyer some damages, the seller would still in effect give the first buyer a chance to renegotiate even if he beheved that the first buyer would not outbid the second buyer. Even if the seller does not suspect that the first buyer values the good more than the second buyer, the seller still has an incentive to inform the first buyer of his intention to breach. The sooner that the first buyer learns of the seller's intention, the easier it will be to minimize the damages that the seller must pay the first buyer.

25. See Kronman, supra note 5, at 353, n.12. 
the first buyer damages. If specific performance is likely to cause costs that exceed damages, there would be an incentive to be even more careful. Initially avoiding the extra costs of specific performance and searching for higher-valued uses also raises costs, however. Parties that bear the extra costs of specific performance would presumably invest in additional searching only until the expected return from finding better matches equals the extra costs. Thus, it is not obvious that the benefits of better initial matches would exceed the costs. Moreover, in cases like our example in which the second buyer's need arises after the original contract, even extra care would not avoid the desire to breach.

\section{Professor Schwartz and the Cost-Increase Argument.}

Professor Schwartz also directly challenges the argument that specific performance raises negotiation costs. ${ }^{26}$ Returning to our example, Schwartz argues that the increased-negotiation rationale is incomplete. If the first buyer can cover from another seller when the seller breaches, specific performance will not increase negotiation costs if the seller can cover as cheaply as the first buyer. Thus, the seller could arrange for a substitute transaction for the first buyer and perform for the second buyer, avoiding negotiation with the first buyer. If the seller's costs of covering exceed the first buyer's, the seller will either cover or negotiate with the first buyer, who will be unable to gaim from the seller more than his advantage in covering. In either case, specific performance increases costs relative to damages when the damage amount is calculable with reasonable certainty. As Schwartz continues:

The issue, then, is whether sellers and buyers generally have similar cover costs. Analysis suggests they do. Sellers as well as buyers have incentives to learn market conditions. Because sellers have to "check the competition," they will have a good knowledge of market prices and quality of ranges. Also, when a buyer needs goods or services tailored to his own needs, he will be able to find such goods or services more cheaply than sellers in general could, for they would first have to ascertain the buyer's needs before going into the market. However, in situations in which the seller and the first buyer lave already negotiated a contract, the seller is likely to have as much information about the buyer's needs as the buyer lias. Moreover, in some markets, such as those for complex machines and services, sellers are likely to have a comparative advantage over buyers in evaluating the probable quality of performance and thus would have

26. See Schwartz, supra note 5, at 284-91. As Schwartz states, the current law is justified in prohibiting sellers from forcing their buyers to perform. See id. at $286 \mathrm{n} .48$. Because selling is a specialized activity, forcing the buyer to resell would raise costs relative to the seller reselling. In terms of protecting subjective value, the rule is correct because sellers are very unlikely to place any value different than that of the market on dollars from a particular buyer. 
lower cover costs. Therefore, no basis exists for assuming that buyers generally have significantly lower cover costs than sellers. It follows that expanding the availability of specific performance would not generate higher post-breach negotiation costs than the damage remedy. ${ }^{27}$

1. Are Cover Costs Equal? Schwartz's analysis may also be incomplete, however. First, buyers have different cover costs. Any buyer will invest in cover up to the point at which the last dollar he spends produces a dollar benefit in lower price or higher quality. Buyers, possessing different needs and abilities, receive different benefits from continuing to search for a desirable seller. For example, a buyer for whom the purchase is particularly important will have an incentive to spend more in searching for prospective sellers. Other buyers may have checked with only one seller. At the time of the breach, some buyers will have better knowledge of prospective substitute sellers than other buyers, and thus have lower cover costs.

If a seller is aware that a buyer's cover costs are more than the seller's, specific performance will not be more costly than damages because the seller will have an incentive to cover for the buyer regardless of the remedy. As Schwartz asserts, sellers will often have specific information about their buyers, including their "sophistication" and their needs under the contract, facts that often will provide rough knowledge of the buyer's likely cover costs relative to the seller's. It does not follow, however, that a seller has an interest in obtaining as much knowledge as all of its potential buyers. Even if the contract reveals the buyer's precise needs, a seller with good knowledge of his competition does not necessarily know as well as the buyer how the competition can satisfy those needs, particularly if they are unusual. Thus, the buyer's original search to fulfill his needs may give him information about substitutes that the seller would need to duplicate at breach. Perhaps buyers who can cover for less than their seller are a small fraction of that seller's customers, but theory cannot tell us that either this percentage or the extra costs of the specific remedy in cases involving such buyers are trivial. For buyers who can cover for less than sellers, specific performance raises costs.

Schwartz also asserts that even if cover costs do differ, post-breach negotiations will not occur. ${ }^{28} \mathrm{He}$ argues that the buyer must make a credible threat before the seller will negotiate, that such a threat will usually require preparing or initiating a lawsuit, and that, because legal

27. Id. at 287.

28. See id. at 288. 
costs will usually exceed the differential in cover costs, credible threats will be rare. ${ }^{29}$ Although these factors will reduce the costs of specific performance, such costs will not be eliminated or even rendered trivial. Because the seller will be uncertain concerning the facts and the buyer's intentions, the seller cannot be positive that any buyer threat to seek - specific performance is idle. A threat costs the buyer far less than a lawsuit would, and the possibility of future breaches by sellers inay encourage the buyer to expend considerable resources to demonstrate his willingness to seek the specific renedy. Even when the probability of the seller successfully "calimg the buyer's bluff" is high, resources will still be spent in the bluffing game that would not be spent under a dainage rule. Further, the possibility of the buyer's threat being carried out may cause the seller to cover even if the buyer has lower cover costs. At ininimuin, the possibility of specific performance increases uncertainty because its use will not be automatic. Increased uncertainty necessarily raises costs to those who prefer more certainty to less. ${ }^{30}$

2. Cases In Which Relative Cover Costs Are Irrelevant. Perhaps more important than relative cover costs are the difficulties Schwartz's argument encounters when certain conditions are met. Two examples illustrate these difficulties. First, consider a situation when performance is less than perfect, as in the famous Jacob \& Youngs, Inc. $v$. Kent ${ }^{31}$ case, in which the contract specified Reading pipe but the seller substituted Cohoes pipe. Courts award damages ineasured either by the cost of completing the job to conform exactly to the specifications or by the diminution in the market value of the structure caused by the deviation. The cost of completion is the cost of specific performance, and it could greatly exceed the drop in market value. In such cases, the non breaching party may be able to obtam substitute performance that is valued at less than that performance's cost, for example, at the drop in market value. ${ }^{32}$ If so, the difference between the two ineasures gives the non-breacher an incentive to demand counpensation for his "right" to specific performance. Negotiation over this coinpensation increases costs relative to the inarket value rule for damages, producing only a

29. Id.

30. Some, however, may prefer uncertainty. See generally Hirshleifer \& Riley, The Analytics of Uncertainty and Information-An Expository Survey, 17 J. ECON. LITERATURE 1375 (1979).

The question of credible threat is related to that of strategic behavior, a subject of considerable dispute among economists. For example, economists disagree about the conditions necessary for predatory pricing, a form of strategic behavior. See McGee, Predatory Pricing Revisited, $23 \mathrm{~J}$. L. \& ECON. 289, 304-26 (1980).

31. 230 N.Y. 239,129 N.E. 889 (1921).

32. See generally Muris, supra note 10. 
redistribution of wealth when subjective value is irrelevant. In such a case, a damage remedy is superior because it eliminates these negotiation costs.

Second, a buyer may claim to value performance from one party inore than the market values that performance. Suppose the buyer orders a specific amount of widgets from Acme corporation, a inanufacturer, equal to the entire output for the next year of Acine's only factory. As evaluated by the inarket, two other inanufacturers make identical widgets, but the buyer claims that he values Acme's widgets more than he values those of the other two supphers. By not revealing this subjective preference durmg negotiations with Acine, however, the buyer can avoid paying inore than the inarket price. Suppose that then a second buyer offers Acine inore than the first buyer, and more than the current price of other sellers. Acme calmot cover by substituting other widgets in supplying the first buyer if he can legally claim to be satisfied only with Acrne widgets. If the first buyer does not truly place a special value on Acine's widgets but only claims to, he can deinand from Acme some of the difference between his cost of purchasing elsewhere and Acme's contract price with the new buyer as coinpensation for his right to specific performance. Because this negotiation only redistributes wealth, its elimination is an unqualified benefit.

3. Lessons From The Two Examples. These examples reveal that if three conditions exist damages are preferable to specific performance regardless of relative cover costs. First, a reasonably easy-to-use dainage ineasure inust be available. Otherwise, it caumot be assumed that negotiations over the proper damage award will cost less than negotiations over the "right" to specific performance. Damages based on proof of the market price at the time of breach ineet this condition in the second example. Whether the drop in inarket value satisfies the condition in the first example is inore difficult to determine. The inarket price of the performance actually received-that is, the performance that did not ineet contract specifications-may not always be as easy to determine as the price of products, such as bread or steel, for which a well defined market exists. If the market price must be established by expert appraisal, the condition of a reasonably easy-to-calculate damage measure may not be inet. The inore costly the market price is to calculate, the more difficult it is to conclude that the costs of negotiation over the specific performance remedy exceed the costs of establishing that price when specific performance is unavailable.

Despite the cost of calculating the inarket price, in at least soine construction cases in which actual performance does not ineet contract 
specifications, specific performance will be a more costly remedy than damages. Damages would be preferable when little or no reasonable disagreement is possible over the market price of the non-conforming performance; as an extreme case, the deviation from the promised performance may not have decreased market value at all, an example of zero damages that has occasionally occurred in litigated decisions. ${ }^{33}$ Whether this example is empirically trivial is unknown. Perhaps more important, even when the market price is not obvious, in at least some of these cases, requiring specific perfornnance is a more costly reinedy than awarding damages. The non-breacher whose loss is less than the cost of correcting the defect in performance has incentive to bargam over specific performance to obtain part of the difference between the correction cost and his loss.

The resources spent negotiating over specific performance or determining the inarket price are limited by the expected return on the "investment" in negotiation. In the case of the market price, well-defined rules of law exist to guide the parties, setting reasonable lower and upper bounds that limit the return froin the investment. In the case of specific performance, however, no such rules exist. The spread, therefore, is potentially as large as the cost of correcting the defects minus the difference between tlie contract price of what was promised and the market price of what was delivered (an ainount equalling the non-breaching party's damage if subjective value is not relevant). Moreover, even with specific performance, the parties will probably spend some resources to estimate the inarket price and thereby find the lower boundary of a possible settlement. These resources will probably not be as great as they are when the 1narket price is determined in court, but they need not be trivial. -Therefore, the size of the amount the parties will bargain over if specific performance is allowed-the cost of correcting the defects minus the market-based damages-will sometimes exceed the amount in dispute if specific performance is not allowed.

If specific performance is not allowed, the only dispute is between the upper and lower reasonable estimates for the inarket price. Thus, in some cases, allowing specific performance will give parties an incentive to spend more on deciding the amount of the "bribe" that the breacher must pay than they would spend in determining the market price. ${ }^{34}$ Although in the aggregate parties may not always spend up to

33. See id.

34. This analysis assumes that the parties do not systematically calculate oue expected return with a different estimate of success than the other. 
expected gains, the higher expected return froin negotiating specific performance creates a tendency to have higher expenditures in such cases. No einpirical information exists on the frequency of the cases in which the disputed amount regarding the market price is less than the ainount over which the parties will bargain with specific performance. This uncertainty, as well as the knowledge that even with specific performance parties will spend resources on estimating the inarket price, places on a weak foundation the assertion that freely granting specific performance will not on balance raise costs coinpared to the current law.

The second condition required for market-based dainages to be preferable to specific performance is that the cost of the performance remedy to the seller exceeds the benefit to the buyer. This is apparent in the first exainple in which the cost of correcting the defects exceeds the drop in market value caused by the defect. The condition is also met in the widget case because the cost to Acine includes the forgone higher price froin the second buyer. Because the price Acine would receive froin the second buyer exceeds the first buyer's cost of buying from another inanufacturer, Acine would lose inore from not delivering to the second buyer than the first buyer would gain froin perforinance froin Acme. If the buyer's benefit from the specific remedy exceeds the seller's costs, then the reinedy is presumptively beneficial and wasteful negotiations will not occur. ${ }^{35}$

Another way to explain this second condition, and to relate it to the first, is that it presuines no difference between subjective and objective values. But because the two ineasures of value could, in fact, differ, awarding the more easily calculable measure of damages could under-protect subjective value and thereby cause extra costs in inoving the resources to their highest use. The question becomes whether protection of subjective value is worth the cost. ${ }^{36}$ Although specific performance is one solution to the problem of protecting subjective value, protection of subjective value does not in itself justify an autoinatic right to the specific remedy because of the possible increases in negotiation costs.

The third condition required for specific performance to increase

35. If the first buyer valued Acme's product more than the others, he would choose specific performance. This choice would avoid rcucgotiation if damages were the first buyer's only rcmedy and the second buyer topped the first buyer's offer but valued the widgets less than the first buyer.

36. See Muris, supra note 10. 
costs is that cover is not possible. ${ }^{37}$ This condition occurs when the buyer can complaim that all cover transactions are madequate. In the case of a dwelling, as in Jacobs \& Youngs, the buyer can claim the importance of the specific site; thus, the breaching party cannot simply build another building elsewhere to the exact specifications of the first contract, deliver it to the purchaser, and then sell the original building to another. With the widgets in the second example, the first buyer can claim that the difference in manufacturers, or some other attribute of the original contract not shared by other possible contracts, makes cover inadequate.

Schwartz does discuss one example in which he admits that specific performance would be a more costly reinedy than damages..$^{38} \mathrm{~A}$ buyer and a seller contract for land to be used for farming in a commumity with many other suitable parcels of such land that could serve as cover if the seller breaches. Another buyer, finding the land to be ideally suited for a restaurant, offers the seller inuch inore than the first buyer. Although Schwartz admits that giving the first buyer the right to specific performance would raise costs by allowing him to demand coinpensation from the seller, ${ }^{39}$ he concludes that specific performance should still be permitted "because the litigation and uncertainty costs" of an exception to an automatic right to specific performance "would probably exceed the excess bargaining costs of making specific performance available in this relatively uncommon situation." 40

These arguments do not support specific performance in all of the deviation from specifications cases, however. Determining that performance deviated from that required in the contract need not be administratively difficult, as cases like Jacobs \& Young illustrate. Nor can this situation be dismissed as empirically trivial, at least if the frequency with which it arises in litigated cases gives any indication. ${ }^{41}$ Of course, what makes deciding these cases more difficult is the possibility that the subjective value and the market value of letter-perfect performance actually differ. In the absence of knowledge that subjective

37. If cover is possible, the relative cost of the remedies then depends on the parties' relative cover costs.

38. See Schwartz, supra note 5, at 288-89.

39. See id. (discussion of the added costs).

40. See id. at 290.

41. Although the cases probably present a distorted picture of the typical business transaction, the frequency of litigation over deviation from specifications gives some evidence that the problem is not trivial. 
value exceeds market value either in a vast inajority of the cases or in only a very few, a per se rule is inappropriate. ${ }^{42}$

How rarely these three conditions are met outside the building cases is unknown. The widget example does not have a case-law analogy, but this could be because inadequacy cannot be shown under the current tests for specific performance, and parties therefore have not sought specific performance. A related problem with the widget example is explaining why the second buyer would pay more for Acme's widgets than for those of other manufacturers. Perhaps the most important situation in which an automatic right to specific performance would raise costs is when the second buyer values Acme's widgets more than those of other sellers while the first buyer merely claims to value Acme widgets more, but-like most other consumers-actually does not. Again, the actual frequency with which such cases occur is of crucial importance and is unknown.

The assumptions in the widget case do, however, raise an important point about Professor Schwartz's analysis and about the protection of subjective value. From a practical standpoimt, his approach is important because it allows those who want specific performance, but who could not now qualify under the uniqueness test, to obtain the specific remedy. Major beneficiaries would be those who regard as unique a good that most people regard as fungible. Yet, the more practical significance his argument has, the more troublesome is the problem of mcreased costs that the Acme example illustrates. Thus, regardless of the parties' relative cover costs, one cannot easily dismiss the possibility of increased costs froin specific performance even in cases not involving construction.

\section{CONCLUSIONS}

Specific performance can protect subjective value when damages do not. Nevertheless, given the current lack of empirical data and the important quahifications to his position, Professor Schwartz's argument for freely granting specific performance is unsatisfactory. If those who desire to change the current legal rules have the burden of persuasion, the uncertainties raised in this coininent reveal that the burden has not been carried. As situations in which buyers can cover at lower costs than the seller and cases involving deviations from specifications illustrate, the cost-raising potential of the specific performance remedy cannot be ignored. Relying on the uniqueness test to determine the

42. This would be especially true if an inexpensive surrogate could be devised to identify those cases in which specific performance is needed to protect subjective value. I argue elsewhere that such a surrogate is possible. See Muris, supra note 10. 
remedy unfortunately does not protect subjective value perfectly. Undoubtedly, courts could improve their application of the test. Given our current knowledge, however, such fine tuning appears more appropriate than complete abandonment of the restrictions on specific performance. 